Економічні науки: збірник наукових праџь Луцького національного технічного університету. - Серія "Регіональна економіка". - Випуск 16 (63). - Редкол.: відп. ред. д.е.н., професор Л.Л. Ковальська - Луцьк : ІВВ Луцького НТУ, 2019. -173 с.

УДК 338.48

Морохович В.С., к.ф-м.н., доцент, доцент кафедри природничогуманітарних та інформаційних дисциплін

Газуда С.М., к.е.н., доцент кафедри менеджменту туристичного та готельно-ресторанного бізнесу

Ужгородський торговельно-економічний інститут КНТЕУ

\title{
КЛЮЧОВІ ІНДИКАТОРИ РОЗВИТКУ ПІДПРИЄМСТВ ГОТЕЛЬНОГО ГОСПОДАРТСВА В ЗАКАРПАТСЬКІЙ ОБЛАСТІ
}

В статті проаналізовано сучасний стан готельного бізнесу Закарпаття. Досліджено рейтинг Закарпатської області серед інших адміністративнотериторіальних одиниць України за показниками експлуатаційної програми. Проаналізовано коефіцієнт використання місткості та показники доходу від наданих готельних послуг.

Ключові слова: індикатори розвитку, готельне господарство, готелі та аналогічні засоби розміщування, готельні послуги, коефіцієнт місткості.

Morokhovich V., Gazuda S.

\section{KEY INDICATORS OF DEVELOPMENT OF THE ENTERPRISES OF HOTEL ECONOMY IN ZAKARPATTIA REGION}

The article analyses the current state of the hotel business in Zakarpattia region. It is noted that to the development of the hotel industry of Zakarpattia region, the growth of tourist flows, contributes the presence of a large number of cultural and historical monuments, as well as the attractiveness of eco-tourism associated with unique natural formations - thermal and therapeutic waters and the like. It is noted that the unique border geographical location of the region, rich natural and ethnic and cultural resource potential of the region provided recognition of the most promising recreational zone in Europe with the possibility of year-round (postseason) service of tourists. Surveying on the Western border of Ukraine with four Central European States - Poland, Slovakia, Hungary and Romania contributes to the development of inexpensive (especially for residents of EU countries) rest, and the predominance of the rural population successfully demonstrates the development of one of the sectors of the tourism industry - rural tourism. It is proved that there is a significant dependence of the activity of the tourist season on weather and climatic conditions. However, the majority of hotel farms of Zakarpattia region even in the most favourable seasons are not busy, which indicates the problems of hotel 

університету. - Серія "Регіональна економіка". - Випуск 16 (63). - Редкол.: відп. ред. д.е.н., професор Л.Л. Ковальська - Луцьк : ІВВ Луиького НТУ, 2019. -173 с.

management. The rating of Zakarpattia region among other administrative and territorial units of Ukraine on indicators of the operational program is investigated. Thus, the number of hotels and similar accommodation facilities in 2017 Zakarpattia ranked third, which makes the region one of the most adapted to receive domestic tourists and foreign citizens. The coefficient of hotel capacity utilization was analyzed. The uneven demand for hotel services was revealed. The problems of seasonality directly affecting the functioning of hotel facilities were revealed. This is a significant influence factor encouraging entrepreneurs to deal with these topical issues of development of the sphere of hotel services. In the process of the study, the assessment of income indicators from the provided hotel services was carried out. It is revealed that the Zakarpattia region in terms of the number of visitors served occupies the seventh position among the regions of Ukraine, which makes the region attractive for attracting investment in the organization of new enterprises. At the same time, the unstable situation in the country affects the performance of the enterprises of the hotel business of the Zakarpattia region and causes the need for redistribution of tourist flows. The share of domestic tourists using hotel services in the region is increasing. The approaches to ensuring the development of the studied sphere are generalized. Therefore, in the hospitality industry contemporary issues an in-depth monitoring hotel management, utilization of research results for development of measures on formation of strategies of development of hotel business in the future. It is reasonable to generalize and use analysis on the demand for tourist and recreational services, improvement of market services, development of scientific and technical programs and projects, attraction of investments into development of enterprises of hotel business in the region, as well as adaptation of constituent entities of the hotel industry of the region to international industry standards and increase of economic efficiency of functioning of the hotel enterprises of the region on the basis of ensuring the training of personnel potential, the development of foreign technologies and management in the hospitality industry. Thus, the development of business in the regions, increasing the status of Ukraine as a country attractive for travel, including foreign tourists, improving the welfare of Ukrainians and the emergence of interest in recreation in the country are the main factors that now determine the growth of demand for hotel services, which is a promising direction for further research.

Key words: development indicators, hotel industry, hotels and similar accommodation facilities, hotel services, capacity factor. 
Економічні науки: збірник наукових праџь Луцького національного технічного університету. - Серія "Регіональна економіка". - Випуск 16 (63). - Редкол.: відп. ред. д.е.н., професор Л.Л. Ковальська - Луцьк : ІВВ Луцького НТУ, 2019. -173 с.

Морохович В.С., Газуда С.Н.

\section{КЛЮЧЕВЫЕ ИНДИКАТОРЫ РАЗВИТИЯ ПРЕДПРИЯТИЙ ГОСТИНИЧНОГО ХОЗЯЙСТВА В ЗАКАРПАТСКОЙ ОБЛАСТИ}

В статье проанализированы современное состояние гостиничного бизнеса Закарпатья. Исследована рейтинг Закарпатской области среди других административно-территориальных единиц Украины по показателям эксплуатационной программы. Проанализированы коэффициент использования вместимости и показатели дохода от предоставленных гостиничных услуг.

Ключевые слова: индикаторы развития, отельное хозяйство, гостиницы и аналогичные средства размещения, гостиничные услуги, коэффициент вместимости.

Постановка проблеми. Економічні, соціальні та адміністративні реформи, в процесі децентралізації влади та задекларована інтеграція України в СС, викликали потребу в системному дослідженні загальних і специфічних властивостей готельного господарства в регіонах, його організації, закономірностей розвитку й управління, формування міжгалузевих й інфраструктурних взаємозв'язків. Зміни охопили широке коло проблем, торкнулися багатьох напрямів обслуговуючої діяльності, привели до появи нових елементів в економічних відносинах системи послуг на конкурентних засадах. У цьому контексті актуальним є висвітлення тенденцій, які зумовлюють подальший розвиток і трансформацію цієї сфери. Оскільки готельне господарство прямо або опосередковано забезпечує робочі місця i в усьому світі $\epsilon$ прибутковою сферою, то і в Україні воно також може давати значні доходи в місцеві бюджети. Тому регіональним органам влади разом 3 бізнесом потрібно створити передумови успішного становлення конкурентоспроможного готельного господарства в Україні.

Аналіз останніх досліджень і публікацій. Теоретичну та інформаційну базу дослідження готельної сфери та сучасних тенденцій іï регіонального розвитку відображено в працях вітчизняних учених: С. Байлика [1], О. Лупич [3], М. Мальської 
Економічні науки: збірник наукових праџь Луцького національного технічного університету. - Серія "Регіональна економіка". - Випуск 16 (63). - Редкол.: відп. ред. д.е.н., професор Л.Л. Ковальська - Луцьк : ІВВ Луцького НТУ, 2019. -173 с.

[4], Я. Остапенко [5], I. Писаревського [6] та ін. Незважаючи на низку публікацій, присвячених розвитку готельного господарства в Україні, процес дослідження цього питання $є$ непереривним і потребує системного підходу.

Цілі статті. Метою статті $є$ дослідження динаміки розвитку готельного господарства Закарпатської області та визначення їі місця серед інших регіонів України.

Виклад основного матеріалу дослідження. Розвитку готельного господарства Закарпатської області, зростанню потоків туристів, сприяє наявність великої кількості культурноісторичних пам'яток, а також привабливість екологічного туризму, пов'язана з унікальними природними утвореннями термальними та лікувальними водами тощо. Існує істотна залежність активності туристичного сезону від погоднокліматичних умов. Однак більшість готельних господарств Закарпатської області навіть у найбільш сприятливі сезони $є$ незавантаженими, що свідчить про проблеми готельного господарювання.

До характеристик пропозиції на підприємствах готельного господарства, які зумовлюють спроможність або неспроможність регіону задовольнити в повному обсязі потреби споживачів у послугах розміщування, належать показники їх експлуатаційної можливості, а саме: кількість готелів та аналогічних засобів розміщування, місткість, коефіцієнт використання місткості тощо.

За кількістю готелів та аналогічних засобів розміщування у 2017 р. Закарпатська область займала третє місце (208 од. юридичні особи та фізичні особи-підприємці) та поступалася Львівській та Івано-Франківській областям (табл. 1). У регіоні за 2014-2017 рр. спостерігається зменшення готелів у загальній кількості (на 9,2 \%). Відзначимо, що в Україні кількість готелів та аналогічних засобів розміщування з 2013 р. по кінець 2017 р. зменшилася 33582 до 2 474, що в процентному відношенні становить 30,9\%. Основними причинами різкого зниження кількості засобів розміщення стали анексія Криму та тимчасова окупація частини Донецької та Луганської областей. 
Економічні науки: збірник наукових праиь Луиького національного технічного університету. - Серія "Регіональна економіка". - Випуск 16 (63). - Редкол.: відп. ред. д.е.н., професор Л.Л. Ковальська - Луцьк : ІВВ Луцького НТУ, 2019. -173 с.

Таблиця 1

Рейтинг Закарпатської області за кількістю готелів та аналогічних засобів розміщування

\begin{tabular}{|c|c|c|c|c|c|c|c|c|c|}
\hline \multirow[b]{2}{*}{ Регіон } & \multicolumn{2}{|c|}{2014} & \multicolumn{2}{|c|}{2015} & \multicolumn{2}{|c|}{2016} & \multicolumn{2}{|c|}{2017} & \multirow[b]{2}{*}{$\begin{array}{c}\text { Темп } \\
\text { при- } \\
\text { росту, } \\
\% \\
2017 / \\
2014\end{array}$} \\
\hline & 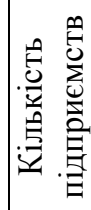 & 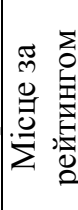 & 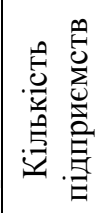 & 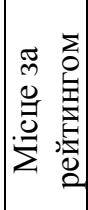 & 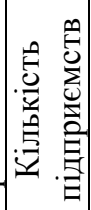 & 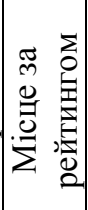 & 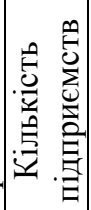 & 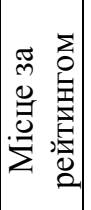 & \\
\hline Львівська & 273 & 1 & 273 & 1 & 287 & 1 & 277 & 1 & 1,5 \\
\hline Івано-Франківська & 212 & 4 & 200 & 4 & 227 & 3 & 244 & 2 & 15,1 \\
\hline Закарпатська & 229 & 3 & 213 & 3 & 211 & 4 & 208 & 3 & $-9,2$ \\
\hline Одеська & 235 & 2 & 250 & 2 & 232 & 2 & 208 & 3 & $-11,5$ \\
\hline м. Київ & 157 & 5 & 147 & 5 & 165 & 5 & 163 & 4 & 3,8 \\
\hline Запорізька & 125 & 7 & 86 & 10 & 114 & 7 & 131 & 5 & 4,8 \\
\hline Дніпропетровська & 146 & 6 & 139 & 6 & 138 & 6 & 120 & 6 & $-17,8$ \\
\hline Харківська & 125 & 7 & 123 & 7 & 108 & 8 & 116 & 7 & $-7,2$ \\
\hline Київська & 89 & 11 & 87 & 9 & 114 & 7 & 111 & 8 & 24,7 \\
\hline Миколаївська & 89 & 11 & 66 & 13 & 74 & 13 & 79 & 9 & $-11,2$ \\
\hline Черкаська & 73 & 13 & 75 & 11 & 80 & 10 & 78 & 10 & 6,8 \\
\hline Україна & 2644 & - & 2478 & - & 2534 & - & 2474 & - & $-6,4$ \\
\hline
\end{tabular}

Джерело: розраховано за даними [2]

Серед областей України за місткістю готелів та аналогічних засобів розміщування Закарпатська область у 2017 р. займала п’яте місце, надаючи 10,2 тис. місць. Майже у два рази більше місць пропонує Львівська область - 18 292. На другому місці м. Київ із показником 17798 ліжко-місць. За 2014-2017 pp. в Закарпатській області спостерігалося 
Економічні науки: збірник наукових праиь Луиького національного технічного університету. - Серія "Регіональна економіка". - Випуск 16 (63). - Редкол.: відп. ред. д.е.н., професор Л.Л. Ковальська - Луцьк : ІВВ Луцького НТУ, 2019. -173 с.

збільшення місць на 0,1 \%, що порівняно із загальним по країні зменшенням ліжко-місць відображує оживлення галузі (табл. 2).

Таблиця 2

Рейтинг Закарпатської області за місткістю готелів

\begin{tabular}{|c|c|c|c|c|c|c|c|c|c|}
\hline \multirow[b]{2}{*}{ Регіон } & \multicolumn{2}{|c|}{2014} & \multicolumn{2}{|c|}{2015} & \multicolumn{2}{|c|}{2016} & \multicolumn{2}{|c|}{2017} & \multirow[b]{2}{*}{$\begin{array}{c}\text { Темп } \\
\text { прир } \\
\text { осту, } \\
\% \\
2017 / \\
2014\end{array}$} \\
\hline & 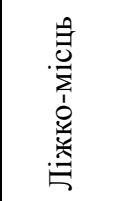 & 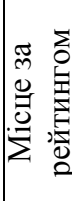 & 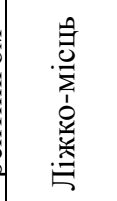 & 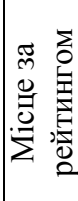 &  & 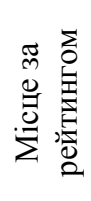 & 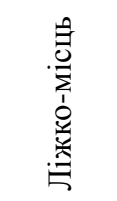 &  & \\
\hline Львівська & 16796 & 2 & 17759 & 2 & 17949 & 2 & 18292 & 1 & 8,9 \\
\hline м. Київ & 21503 & 1 & 20484 & 1 & 18326 & 1 & 17798 & 2 & $-17,2$ \\
\hline $\begin{array}{l}\text { Івано- } \\
\text { Франківська }\end{array}$ & 8754 & 5 & 8576 & 5 & 10790 & 4 & 11082 & 3 & 26,6 \\
\hline Одеська & 11863 & 3 & 12402 & 3 & 12096 & 3 & 11021 & 4 & $-7,1$ \\
\hline $\begin{array}{l}\text { Закарпат- } \\
\text { ська }\end{array}$ & 10160 & 4 & 9466 & 4 & 10658 & 5 & 10169 & 5 & 0,1 \\
\hline $\begin{array}{l}\text { Дніпропет- } \\
\text { ровська }\end{array}$ & 8341 & 6 & 8096 & 6 & 7740 & 6 & 7758 & 6 & $-7,0$ \\
\hline Запорізька & 6956 & 7 & 6045 & 7 & 6611 & 7 & 7373 & 7 & 6,0 \\
\hline Харківська & 5759 & 8 & 5559 & 8 & 5381 & 8 & 5633 & 8 & $-2,2$ \\
\hline Київська & 4758 & 9 & 4960 & 9 & 5277 & 9 & 5345 & 9 & 12,3 \\
\hline Полтавська & 4113 & $\begin{array}{l}1 \\
0 \\
\end{array}$ & 4172 & 10 & 3993 & 10 & 4052 & 10 & $-1,5$ \\
\hline Україна & 135518 & - & 132535 & - & 135916 & - & 133396 & - & $-1,6$ \\
\hline
\end{tabular}

Джерело: розраховано за даними [2]

Закарпаття, за показниками кількості осіб, що перебували у готелях та аналогічних засобах розміщування у 2017 р. займає сьому позицію, поступаючись Києву, Львівській, ІваноФранківській, Харківській, Одеській, Київській областям (табл. 3). 
Економічні науки: збірник наукових праџь Луцьького національного технічного університету. - Серія "Регіональна економіка". - Випуск 16 (63). - Редкол.: відп. ред. д.е.н., професор Л.Л. Ковальська - Луцьк : ІВВ Луцьккого НТУ, 2019. -173 с.

Таблиця 3

Рейтинг Закарпатської області за кількістю осіб, що перебували у готелях та аналогічних засобах розміщування

\begin{tabular}{|c|c|c|c|c|c|c|c|c|c|c|}
\hline \multirow[b]{2}{*}{ Регіон } & \multicolumn{2}{|c|}{2014} & \multicolumn{2}{|l|}{2015} & \multicolumn{2}{|l|}{2016} & \multicolumn{2}{|l|}{2017} & \multirow[b]{2}{*}{ 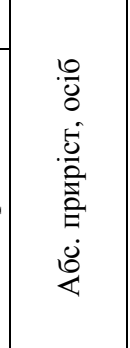 } & \multirow[b]{2}{*}{ 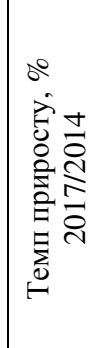 } \\
\hline & 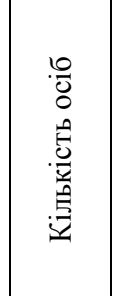 & 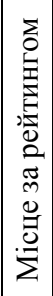 & 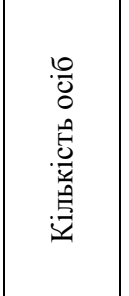 & 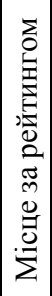 & 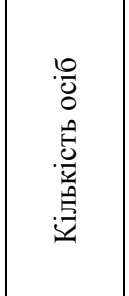 & 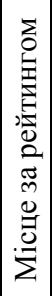 & 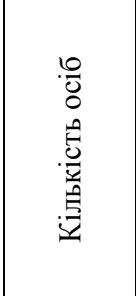 & 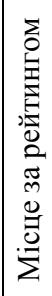 & & \\
\hline м. I & 47631 & 1 & 327 & 1 & 789 & 1 & 041 & 1 & 274410 & 32,3 \\
\hline Львів & ) & 2 & 2 & 2 & 5 & 2 & 871401 & 2 & 221 & 400 \\
\hline & 2 & 3 & 914 & 3 & 4805 & 3 & 2 & 3 & 3070 & 1,98 \\
\hline & & 5 & & 5 & & 7 & & Ir & & 23,48 \\
\hline Од & 32 & 6 & 586 & 4 & 27 & 4 & 252101 & 5 & 19 & 39,07 \\
\hline Київс & 175776 & 7 & 161327 & 9 & 249797 & 5 & 250 & 6 & 74892 & 42,61 \\
\hline Закарпа7 & 142466 & 9 & 470 & 8 & 4350 & 8 & 00 & 7 & 95434 & 66,99 \\
\hline & 05234 & 4 & 211345 & 6 & 8453 & 6 & 14379 & 8 & 9145 & 4,46 \\
\hline Полтавська & 134794 & 10 & 172931 & 7 & 173137 & 10 & 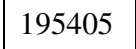 & 9 & 60611 & 14 \\
\hline Хмельни & 48674 & 8 & 152037 & 10 & 170167 & 11 & 170110 & 10 & 21436 & 14,42 \\
\hline Україна & 3814201 & - & 4297190 & - & 5037075 & - & 5135164 & - & 1320963 & 34,63 \\
\hline
\end{tabular}

Джерело: розраховано за даними [2]

За період 2014-2017 pp. спостерігалося поступове збільшення кількості приїжджих як по Україні, так і в Закарпатській області, після кризи 2013-2014 pp. це $\epsilon$ позитивною тенденцією, яка супроводжувалася перерозподілом рейтингових позицій серед регіонів України. За досліджуваний період Закарпатська область в абсолютних показниках збільшила загальну кількість обслугованих приїжджих у підприємствах готельного господарства на 95434 осіб (близько 
Економічні науки: збірник наукових праџь Луцького національного технічного університету. - Серія "Регіональна економіка". - Випуск 16 (63). - Редкол.: відп. ред. д.е.н., професор Л.Л. Ковальська - Луцьк : ІВВ Луцького НТУ, 2019. -173 с.

$67 \%$ ). Рейтингова оцінка Закарпатської області піднялася 3 дев' ятого місця у 2014 р. на сьому позицію у 2017 р.

Зазначимо, що внаслідок політичної нестабільності та бойових дій на сході країни, а також 3 анексією Криму, Закарпаття стало одним 3 найбільш привабливих i перспективних регіонів з точки зору розвитку туризму. Його унікальне прикордонне географічне розташування, багатий природно- й етнокультурно-ресурсний потенціал забезпечили області визнання найбільш перспективної рекреаційної зони Європи 3 можливістю цілорічного (позасезонного) обслуговування туристів. Межування на західному кордоні України 3 чотирма центральноєвропейськими державами Польщею, Словаччиною, Угорщиною і Румунією - сприяє розвитку недорогого (особливо для мешканців країн Свросоюзу) відпочинку, а переважання сільського населення краю успішно демонструє розвиток одного із секторів розвитку туристичної галузі - сільського зеленого туризму.

Одним з основних показників ефективності експлуатації готельного господарства вважають коефіцієнт використання місткості, що дає інформацію про завантаження готелю в окремо взятий період часу. Закарпатська область серед готелів та аналогічних засобів розміщування за цим коефіцієнтом займає дев'яте місце $(21,0 \%)$, що порівняно 3 середньоукраїнським показником $(24,0 \%) \in$ досить низьким результатом. Це свідчить про нерівномірний попит на готельні послуги. Сезонність також має вплив на розвиток досліджуваної сфери регіону є актуальним питанням для підприємців.

За коефіцієнтом використання місткості в цій сфері регіону за період 2014-2017 рр. спостерігається його поступове зростання - 315,0 \% у 2014 р. до 21,0\% у 2017 р., хоча показники 2014 р. були рекордно низькими (табл. 4). 
Економічні науки: збірник наукових праџь Луцьького національного технічного університету. - Серія "Регіональна економіка". - Випуск 16 (63). - Редкол.: відп. ред. д.е.н., професор Л.Л. Ковальська - Луцьк : ІВВ Луцьккого НТУ, 2019. -173 с.

Таблиця 4

Рейтинг Закарпатської області за коефіцієнтом використання місткості (КВМ) готелів*

\begin{tabular}{|c|c|c|c|c|c|c|c|c|}
\hline \multirow[b]{2}{*}{ Регіон } & \multicolumn{2}{|c|}{2014} & \multicolumn{2}{|c|}{2015} & \multicolumn{2}{|c|}{2016} & \multicolumn{2}{|c|}{2017} \\
\hline & КВМ &  & KBM & 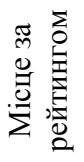 & КВМ & 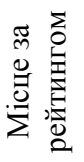 & КВМ & 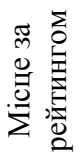 \\
\hline Волинська & 0,28 & 2 & 0,32 & 2 & 0,30 & 2 & 0,34 & 1 \\
\hline м. Київ & 0,27 & 3 & 0,28 & 3 & 0,32 & 1 & 0,33 & 2 \\
\hline Запорізька & 0,32 & 1 & 0,27 & 4 & 0,28 & 3 & 0,28 & 3 \\
\hline Черкаська & 0,16 & 13 & 0,18 & 9 & 0,19 & 10 & 0,28 & 3 \\
\hline Львівська & 0,26 & 4 & 0,21 & 6 & 0,25 & 5 & 0,26 & 4 \\
\hline Полтавська & 0,20 & 9 & 0,21 & 6 & 0,21 & 9 & 0,26 & 4 \\
\hline Херсонська & 0,16 & 13 & 0,18 & 9 & 0,24 & 6 & 0,26 & 4 \\
\hline Рівненська & 0,26 & 4 & 0,27 & 4 & 0,25 & 5 & 0,25 & 5 \\
\hline Донецька & 0,17 & 12 & 0,21 & 6 & 0,19 & 10 & 0,25 & 5 \\
\hline Харківська & 0,19 & 10 & 0,19 & 8 & 0,22 & 8 & 0,24 & 6 \\
\hline Вінницька & 0,16 & 13 & 0,16 & 10 & 0,19 & 10 & 0,23 & 7 \\
\hline $\begin{array}{l}\text { Дніпро- } \\
\text { петровська }\end{array}$ & 0,25 & 5 & 0,21 & 6 & 0,23 & 7 & 0,23 & 7 \\
\hline Київська & 0,18 & 11 & 0,14 & 11 & 0,19 & 10 & 0,22 & 8 \\
\hline Хмельницька & 0,23 & 7 & 0,25 & 5 & 0,23 & 7 & 0,22 & 8 \\
\hline Закарпатська & 0,15 & 14 & 0,19 & 8 & 0,19 & 10 & 0,21 & 9 \\
\hline Луганська & 0,15 & 14 & 0,37 & 1 & 0,22 & 8 & 0,21 & 9 \\
\hline $\begin{array}{l}\text { Івано- } \\
\text { Франківська }\end{array}$ & 0,19 & 10 & 0,25 & 5 & 0,24 & 6 & 0,20 & 10 \\
\hline $\begin{array}{l}\text { Кіровоград- } \\
\text { ська }\end{array}$ & 0,14 & 15 & 0,20 & 7 & 0,21 & 9 & 0,20 & 10 \\
\hline Миколаївська & 0,18 & 11 & 0,18 & 9 & 0,21 & 9 & 0,20 & 10 \\
\hline Сумська & 0,21 & 8 & 0,19 & 8 & 0,22 & 8 & 0,20 & 10 \\
\hline Україна & 0,21 & - & 0,22 & - & 0,23 & - & 0,24 & - \\
\hline
\end{tabular}

Джерело: сформовано за даними [2] 
Економічні науки: збірник наукових праџь Луцького національного технічного університету. - Серія "Регіональна економіка". - Випуск 16 (63). - Редкол.: відп. ред. д.е.н., професор Л.Л. Ковальська - Луцьк : ІВВ Луцького НТУ, 2019. -173 с.

За обсягом доходу від надання послуг готелями та аналогічними засобами розміщування Закарпатська область протягом 2014-2017 рр. займала восьме місце, поступаючись м. Києву, Львівській, Івано-Франківській та іншим областям (табл. 5).

Таблиця 5

Рейтинг Закарпатської області за доходами від наданих послуг готелями та аналогічними засобами розміщування*

\begin{tabular}{|c|c|c|c|c|c|c|c|c|c|c|}
\hline \multirow[b]{2}{*}{ Регіон } & \multicolumn{2}{|c|}{2014} & \multicolumn{2}{|c|}{2015} & \multicolumn{2}{|l|}{2016} & \multicolumn{2}{|c|}{2017} & \multirow[b]{2}{*}{  } & \multirow[b]{2}{*}{ 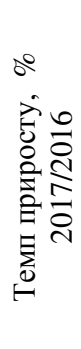 } \\
\hline & 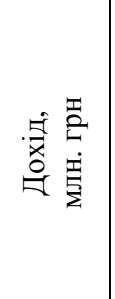 & 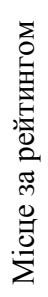 & 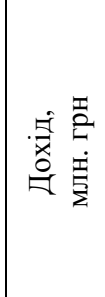 & 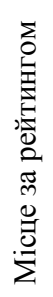 &  & 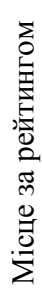 &  &  & & \\
\hline м. Київ & 1420,7 & 1 & 2253,7 & 1 & 2932,1 & 1 & 4033,8 & 1 & 1101,7 & 37,6 \\
\hline Львіг & 449,8 & 2 & 842,3 & 2 & 991,9 & 2 & 1352,2 & 2 & 360,3 & 36,3 \\
\hline $\begin{array}{l}\text { Івано- } \\
\text { Франківська }\end{array}$ & 203,2 & 3 & 334,4 & 3 & 448,1 & 3 & 525,5 & 3 & 77,4 & 17,3 \\
\hline Одеська & 187,2 & 4 & 298,8 & 4 & 444,6 & 4 & 443,5 & 4 & $-1,1$ & $-0,2$ \\
\hline Київсь & 138,4 & 6 & 178,7 & 6 & 242,7 & 6 & 347,5 & 5 & 104,8 & 43,2 \\
\hline Харкіг & 118,8 & 7 & 156,2 & 7 & 244,0 & 5 & 333,3 & 6 & 89,3 & 36,6 \\
\hline $\begin{array}{l}\text { Дніпро- } \\
\text { петровська }\end{array}$ & 149,9 & 5 & 188,9 & 5 & 228,8 & 7 & 245,1 & 7 & 16,3 & 7,1 \\
\hline Закарг & 113,1 & 8 & 142,0 & 8 & 190,7 & 8 & 229,7 & 8 & 39,0 & 20,5 \\
\hline Полтавська & 56,5 & 11 & 77,4 & 11 & 112,7 & $\begin{array}{l}1 \\
0 \\
\end{array}$ & 158,8 & 9 & 46,1 & 40,9 \\
\hline Запорізька & 77,4 & 10 & 80,4 & 10 & 117,1 & 9 & 151,5 & 10 & 34,4 & 29,4 \\
\hline Україна & 3404,5 & - & 5112,1 & - & 6710,2 & - & 8629,3 & - & 1919,1 & 28,6 \\
\hline
\end{tabular}

*Джерело: розраховано за даними [2]

Загальний дохід у 2017 р. становив 229,7 млн. грн., що на 39,0 млн. грн. більше, ніж у 2016 р. Якщо порівняти дохід 
Економічні науки: збірник наукових праџь Луцького національного технічного університету. - Серія "Регіональна економіка". - Випуск 16 (63). - Редкол.: відп. ред. д.е.н., професор Л.Л. Ковальська - Луцьк : ІВВ Луцького НТУ, 2019. -173 с.

готельних підприємств Закарпаття та м. Києва, отримаємо різницю у 17,5 рази, що є значним відставанням.

Висновки і перспективи подальших досліджень. На основі проведеного дослідження можна констатувати формування певних тенденцій сучасного стану та розвитку готельного господарства Закарпатської області:

- за кількістю готелів та аналогічних засобів розміщування у 2017 р. Закарпаття займало третє місце, що робить регіон одним iз найбільш адаптованих для прийому внутрішніх туристів, а також іноземних громадян;

- коефіцієнт використання місткості готелів свідчить про нерівномірний попит на готельні послуги; проблема сезонності впливає на готельне господарювання та спонукає підприємців займатися цим актуальним питанням;

- Закарпатська область за показником кількості обслугованих приїжджих займає сьому позицію серед регіонів України, що робить край привабливим для залучення інвестицій на організацію нових підприємств;

- нестабільна ситуація в країні впливає на показники діяльності підприємств готельного бізнесу Закарпатської області та спричиняє необхідність перерозподілу туристичних потоків. Збільшується питома вага внутрішніх туристів, що користуються готельними послугами в регіоні.

У готельному бізнесі області актуальними $є$ :

- необхідність проведення поглибленого моніторингу готельного господарювання, використання результатів дослідження для розробки заходів щодо формування стратегій розвитку готельного бізнесу на перспективу;

- узагальнення і використання аналітичної інформації про попит на туристично-рекреаційні послуги, удосконалення ринку послуг;

- розробка науково-технічних програм і проектів залучення інвестицій у розвиток підприємств готельного бізнесу в регіоні;

- адаптація суб'єктів готельного господарювання регіону до світових стандартів галузі; 
Економічні науки: збірник наукових праџь Луцького національного технічного університету. - Серія "Регіональна економіка". - Випуск 16 (63). - Редкол.: відп. ред. д.е.н., професор Л.Л. Ковальська - Луцьк : ІВВ Луцького НТУ, 2019. -173 с.

- підвищення економічної ефективності функціонування готельних підприємств регіону на основі забезпечення професійної підготовки кадрового потенціалу, освоєння зарубіжних технологій господарювання в готельному бізнесі.

Розвиток бізнесу в регіонах, підвищення статусу України як країни, привабливої для подорожей, зокрема іноземними туристами, підвищення добробуту українців і поява інтересу до відпочинку всередині країни є основними чинниками, що нині визначають зростання попиту на послуги готельних підприємств, що $є$ перспективним напрямом подальших досліджень.

1. Байлик С.І., Писаревський І.М. Організація готельного господарства: підручник. Харків: ХНУМГ ім. О.М. Бекетова, 2015. 329 с.

2. Державна служба статистики України: регіональна статистика. URL: http://www.ukrstat.gov.ua

3. Лупич О.О. Вплив сучасних тенденцій індустрії гостинності на перспективи іiі розвитку в Україні // Науковий вісник Ужгородського університету. Серія «Економіка». 2016. №1(2). С. 78-82.

4._Мальська М.П., Пандяк І.Г. Готельний бізнес: теорія та практика: підручник. К.: Центр учбової літератури, 2012. 472 с.

5. Остапенко Я.О. Статистичний аналіз підприємств готельного господарства та прогнозування його розвитку // Глобальні та національні проблеми економіки. 2015. Вип. 8. С. 1216-1221.

6. Писаревський I.M., Сегеда I.В. Тенденції розвитку готельного господарства в регіоні: вектор пріоритетів // Комунальне господарство міст. Серія: Економічні науки. 2014. Вип. 115. С. 83-87. 